\title{
De geestelijk gestoorde tussen wal en schip
}

\author{
R. Drenth*
}

Bij deze titel denk ik aan twee verschillende categorieën mensen. Die categorieën hebben niet zo erg veel met elkaar gemeen, denk ik.

Ik doel op de categorie waar ik alleen maar via de BOPZ mee in aanraking kom en een andere categorie, die ik in eerste instantie via het strafrecht leer kennen.

Bij de eerste categorie, die in het BOPZ-kader valt, tref ik van tijd tot tijd iemand aan van wie ik het gevoel heb dat er iets niet deugt, zonder dat ik precies kan aangeven waar het knelt. Ik weet dus niet precies waar het schip is en waar de wal. Ik vind dat ik (juist) in dit gezelschap daar iets over kan, of eigenlijk zelfs moet zeggen.

\section{BOPZ-recht}

Het gaat om de mensen die herhaaldelijk te kennen geven dat ze niet langer willen leven. De geijkte reactie op een suïcide-wens is het vragen van een rechterlijke machtiging (RM) omdat de persoon in kwestie een gevaar voor zichzelf vormt. De suïcide-wens wordt veelal gezien als een uiting van een gestoorde geest. Een geestelijk gezond mens wil toch leven?

Ik zou met deze redengeving misschien best kunnen leven, ware het niet dat ik in het kader van strafzaken rond levensbeëindiging steeds weer heel nadrukkelijk geconfronteerd wordt met de vrijheid van personen om behandeling te weigeren. En daar wringt het nog wel eens, dunkt mij. Vinden we niet te gemakkelijk dat iemand wel gestoord moet zijn als hij/zij niet meer wil leven? Op grond waarvan wordt de geestesziekte gediagnostiseerd? Alleen op de stervenswens? Wordt er wel steeds recht gedaan aan degene die niet meer wil leven door hem/haar gedwongen te behandelen en daarmee in leven te houden? In de meeste gevallen wel, denk ik, maar soms twijfel ik wel eens. Niet iedereen vindt een psychiater als Chabot. ${ }^{1}$ Eerlijk gezegd zou ik ook niet

*Officier van justitie te Groningen.

1 HR 21 juni 1994, NJ 1994, 656 m.nt. Sch. 
goed weten hoe je met deze personen dan wél om moet gaan. Ik breng het hier naar voren in de hoop dat er eens wat over doorgepraat zal worden.

\section{Strafrecht}

Bij het bedenken van het thema voor deze dag zal wel meer aan de andere categorie gedacht zijn. De categorie van overlastbezorgers van wie je steeds weer afvraagt of een reactie op zijn/haar gedrag via het strafrecht of via de een of andere vorm van behandeling het eerst in aanmerking komt. Vaak is het min of meer toevallig welke route bewandeld wordt. In beide routes is het echter niet eenvoudig om betrokkene voor een iets langere tijd intramuraal onder controle te houden. Het gaat meestal niet om echt gevaarlijke personen, maar meer om onaangepast gedrag waarvoor de omgeving (al dan niet terecht) bang is. Opnames voor behandeling kunnen dus eigenlijk alleen op vrijwillige basis plaatsvinden. Maar hoe motiveer je iemand tot een opname als dat betekent dat allerlei vrijheden ineens niet meer gelden?

Als er al eens een gedwongen opname door een inbewaringstelling (IBS) gerealiseerd wordt, is het meestal naar aanleiding van een incident. Tegen de tijd dat over verlenging van de inbewaringstelling beslist moet worden is het acute gevaar al weer geweken, wordt een vordering verlenging afgewezen en krijg ik de politie aan de telefoon met de vraag of ik misschien procedureel iets verkeerd gedaan heb, want die en die is alweer los en of dat nu allemaal zo maar kan; die rechters begrijpen er ook niks meer van tegenwoordig.

Iedere keer weer probeer ik uit te leggen dat de wet nu eenmaal is zoals die is en dat een rechter er toch voor is om de wet toe te passen, maar echt begrijpen doen ze het vaak niet. Zij zitten opnieuw met een overlastprobleem. De buurt klaagt weer en als het een beetje tegen zit, komt de burgemeester ook nog eens vragen of er nu echt niks aan te doen is. De strafrechtelijke route levert dus een al even triest beeld op. Het gaat immers vooral om last door relatief geringe delicten. De frequentie van de delicten kan nog wel eens aanleiding zijn om langs de strafrechtelijke weg iets meer te doen. Maar dat "iets meer" is alleen maar een iets langere insluiting in een politie- of HvB-cel. Voordat het zover is heeft de betrokkene al een heel aantal in persoon uitgereikte dagvaardingen op zak die dan allemaal bij elkaar gevoegd worden. $\mathrm{Na}$ het uitreiken van elke dagvaarding gaat betrokkene weer de straat op. Naar huis kun je meestal niet zeggen omdat er vaak helemaal geen huis is. 
Maar de celcapaciteit wordt niet in de eerste plaats voor deze lieden vrijgemaakt. Integendeel, deze mensen worden vaak het eerst heengezonden als er weer eens een zwaarder geval opgepakt is. De zwaarte wordt dan altijd afgemeten aan de ernst van het delict, niet aan de behoefte van verdachte aan behandeling of onderdak. Als hij/zij behandeld wil worden kan dat immers op vrijwillige basis - in theorie tenminste en daar verschuilen we ons dan maar achter. De politiecel is er natuurlijk ook niet echt om iemand voor te bereiden op een psychiatrische behandeling of iets dergelijks. Maar goed, betrokkene is aangehouden en heeft op een gegeven moment zoveel zaken/zaakjes open staan dat er tot een voorgeleiding wordt besloten.

Als OvJ denk je dan al goed bezig te zijn door een gerechtelijk vooronderzoek (GVO) te vorderen waarbinnen een onderzoek naar de geestvermogens wordt gedaan. De rechter-commissaris (RC) stuurt de districtspsychiater langs om te bezien of psychiatrische rapportage van belang is. Als er al gerapporteerd wordt komt er een advies tot behandeling. Dat advies leidt in het gunstigste geval tot een (gedeeltelijk) voorwaardelijke veroordeling en dan zijn we aangeland op het punt waar we langs de andere route waren bij de verlenging van de IBS. Een onvoldoende gemotiveerde veroordeelde maakt de behandeling niet af en loopt op enig moment tegen een vordering tot tenuitvoerlegging op. De problemen met de betekening van zo'n vordering laat ik hier onbesproken. Voordat de vordering tenuitvoerlegging gemaakt en betekend is, zijn er al weer nieuwe dagvaardingen uitgereikt. Diefstal van een brood, van een fles wijn, van een reep chocola, een vernieling, een mishandeling, enzovoort.

\section{Schieten de regels te kort?}

Allemaal doen we ons best wetten uit te voeren zoals ze bedoeld zijn en allemaal krijgen we een katterig gevoel bij dit soort van zaken. Want we bereiken zo weinig. Zijn die wetten dan niet goed? Of voeren we ze niet goed uit? Binnen de kaders die we de laatste jaren in onze wetgeving hanteren mankeert er, dunkt mij, niet zo veel aan de wetten. 
Ze worden volgens mij ook redelijk netjes nageleefd, afgezien van wat incidentjes misschien. Maar wordt er soms aan andere wetten te weinig aandacht besteed? Zou een groot deel van de probleemgevallen waar we nu over praten niet uit de wereld zijn als we meer geld over hadden voor zaken die deze probleemgevallen kunnen voorkomen?

U zult van de sprekers van vandaag, hoop ik, niet verwachten dat ze met kant en klare oplossingen komen. Ik heb ze in elk geval niet. Ik heb vooral veel vragen. Door die vragen maar hardop te stellen hoop ik een heel klein beetje mee te werken aan een discussie die misschien wel tot oplossingen kan leiden. Want het kan niet de bedoeling zijn dat steeds meer mensen tussen wal en schip terecht komen. Op den duur zou immers onze hele (zogenaamd?) beschaafde maatschappij verzuipen. 